\title{
Influence of portal hypertension on the state of the hemomicrocirculatory level of rat skin: morphological study
}

\author{
N.R. Grytsevych ${ }^{1}$, V.V. Vereschaka ${ }^{2}$ \\ ${ }^{1}$ Higher educational communal institution of the Lviv regional council "Andrei Krupinsky Lviv Medical \\ Academy", Lviv; \\ ${ }^{2}$ Educational and Scientific Center "Institute of Biology and Medicine" of Taras Shevchenko National \\ University of Kyiv; Kyiv, vvv090675@gmail.com
}

The effect of portal hypertension on the condition of the hemomicrocirculatory tract of the skin male white nonlinear rats was studied. Hypertension was simulated by applying a ligature to the portal vein according to the conventional method. After 30, 60 and 90 days, skin biopsies were taken from the anterior abdominal wall for optical microscopy examination, which was subjected to routine histological processing. In animals of the control group, which underwent sham surgery, the skin remained unchanged. In rats of the experimental group after 30 days in the basal layer of the epidermis there were cells with signs of degenerative changes. The basement membrane of the epidermis had small areas with thinning and thickening, which in both cases were accompanied by the formation of small and massive leukocyte infiltrates. Its edema was noted, which extended to the papillary and reticular layer of the dermis. Elastic fibers were unchanged. Only $50 \%$ of the microvessels looked intact, 20\% microvessels were narrowed, and 30\% had signs of stagnant hyperemia due to dilatation. After 60 days the epidermis was thinned, in the basal layer the cells with picnotized and displaced to the periphery nucleus were detected. In all studied layers of epidermis, besides reticular layer, expansion of arterioles, venules and capillary loops was observed. After 90 days the epidermis was represented by 3-6 layers of cells, its general refinement was observed due to the reduction of the thickness of the spinous and granular layers with simultaneous thickening of the horny layer. In the papillary layer of the dermis, the number of thin-walled blood vessels was increased. The average diameter of the arterioles of the hypodermis decreased relative to the values on the 60th day. The mean diameter of the arterioles of the subdermal network on the border of the papillary and reticular layers and capillary loops under the basal membrane was reduced what can be a sign of sclerotic changes in the microvessels. The venules diameter remained increased. In arterioles and venules, stasis of the microvessels, edema of their walls, microaneurysm, and venous sacculation were detected. Thus, we believe that the changes in the microvessels of the skin, which are observed in portal hypertension, are the result of hemodynamic disturbances in the tissue, which is a complex chain of hemomicrocirculatory flow to the direct action of hypertension in the portal vein and is a secondary response to systemic vascular damage.

Key words: portal hypertension; morphology; skin; hemomicrocirculation.

\section{INTRODUCTION}

During 2016-2019, more than 170000 urgent surgical interventions were performed in Ukraine every year [1]. The same article presents an interview with the director of the National Institute of Surgery and Transplantology named after O.O. Shalimov of the National Academy of Medical Sciences of Ukraine Oleksandr Usenko,

(C) N.R. Grytsevych, V.V. Vereschaka who emphasized that "the volume of planned surgery during the last 4 years (2015-2019) has remained approximately constant: about 270 thousand operations on abdominal organs were performed annually". There are statistics on other types of surgical interventions, there are no statistics only on plastic surgery [2]. In general, the number of surgical interventions is impressive. Therefore, the problem of skin repair 
in the surgical field was and remains an urgent problem today.

The rate of healing and the formation of a normal scar is influenced by many factors, among which a significant role belongs to the state of the hemomicrocirculatory tract of the skin [35]. Surgical complications arising from vascular changes, especially against the background of low blood pressure, can lead to disruption of pro- and antioxidant homeostasis, fibrotic changes in connective tissue structures, sclerotic microvascular lesions, lipoid necrobiosis. However, the structural mechanisms of these changes remain unclear, despite a large number of studies on the morphological changes of the skin in surgical complications.

Due to the fact that with the development of portal hypertension develops hypotension [6], the aim of the study was to investigate the influence of portal hypertension on the state of the hemomicrocirculatory level of rat skin in dynamics.

\section{METHODS}

The investigations were performed on 20 male white nonlinear rats aged 5 months which were randomly divided into 2 groups of 10 animals in each. In rats of the first (control) group, a sham operation was performed. In rats of the second group, portal hypertension was simulated by applying a ligature to the portal vein according to the conventional method $[7,8]$. After 30,60 and 90 days, under local anesthesia skin biopsies were taken.

The obtained skin bioptates for optical microscopy research were fixed in $10 \%$ solution of neutral formaldehyde and subjected to routine histological treatment $[9,10]$. Histologic slices were stained with hematoxylin and eosin, picrofuchsin according to VanGyzon method after incubation in collagenase solution, as well as without it, with picroindigo carmine, according to Mallory using phosphomolybdic acid, according to Cason, resorcinum-fuchsin according to Weigert, aldehyde-fuchsin according to Gomori after processing of slices with and without acetic acid, with Verhoeff's hematoxylin, toluidine blue with testicular hyaluronidase treatment of control slices, according to the Schiff method using iodic acid after treatment with salivary amylase in McManu's modification, via impregnation of silver according to Foote, also according to the method of Missime, according to the Pearls method using the reaction of the Berlin azure by Leeson, staining according to Gandhi and Mainini, according to Coss, according to the Mccallum method, by the Congo Red, according to Cason, according to Romanovsky-Giemsa, according to the MayGrunwald method. The average diameters, area and volume of histological structures were determined according to the formulas proposed by Avtandilov [11]:

$$
\begin{gathered}
S=\frac{\pi}{4} \times A B \\
V=\frac{\pi^{4}}{48} \times \sqrt{(A B)^{3}},
\end{gathered}
$$

where A is a long diameter, B is a short diameter.

Morphometric analysis was performed using UTHSCSA ImageJ software available on the Internet at ftp://maxrad6.uthscsa.edu.

Statistical methods. The obtained research results were checked for the normality of the distribution using the W Shapiro-Wilk test. As our data were normally distributed, the samples were compared using Student's t-test. The results were expressed as the mean $\mathrm{M} \pm \mathrm{m}$. For our data, we took the level of significance $\mathrm{P}<$ 0.05 [12].

\section{RESULTS}

Light microscopy showed that skin in intact animals (I group) was of typical structure. The horny layer of epidermis consisted of several rows of toughly bound horny scales which were evenly filled with keratin. Between the keratinocytes of the spinous and granular layers clear intracellular spaces were identified. 
Basal epidermocytes are of cylindropodic form and have a prolate nucleus (Fig. 1). Dermal fibroblasts were characterized by moderate basophilia. The architectonics of collagen fibers corresponded to their localization: in the upper layer of the dermis, the fibers were dense and fine-fibrous, in the middle - loose and relatively enlarged, in the bottom they were well structured given the increase of their density and linear dimensions and formed bundles (Fig. 2).

Reticulin fibers and pathological inclusions in the dermis have not been identified. The elastic fibers were predominantly located in the reticular layer of the dermis, they were identified as gyros' cylinder- and ribbon-like structures of elongated shape that were well contoured. Most of them surrounded blood vessels, hair follicles, sebaceous and sweat glands, pierced, and wrapped collagen fibers. Tissue basophils in the dermis and hypodermis were localized peri vascularly. Papillary layer of the dermis was represented by elongated inactive basophils in a state of rest, only a small part of them degenerated. In the reticular layer of the dermis, tissue basophils acquired spherical form, increased in volume, and raised their functional activity in contrast to the papillary layer. Dermal microvessels were presented by

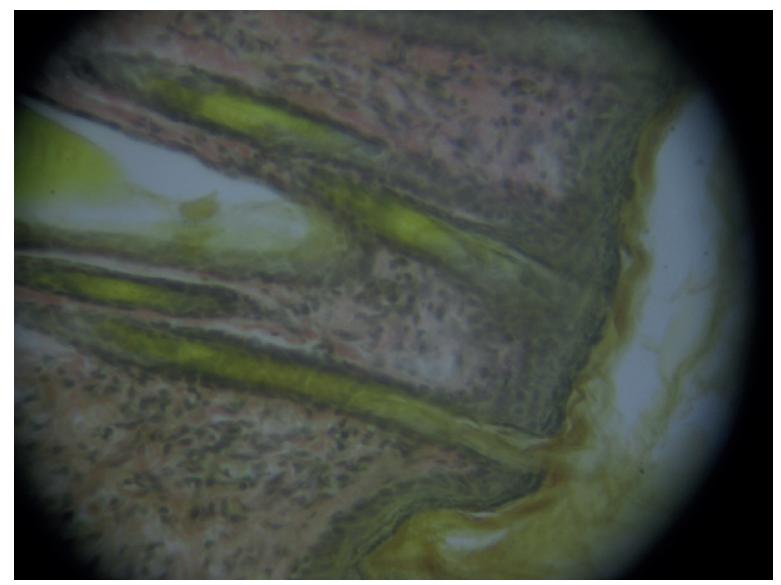

Fig. 1. The horny layer of epidermis consisted of several rows of toughly bound horny scales. Basal epidermocytes are of cylindropodic form and have a prolate nucleus. The skin of the anterior abdominal wall of 5-months-old rat. Staining with hematoxylin and eosin. 400× assorted horizontal plexus. In the hypodermis, a wide loop vascular network was seen, consisting of arteriolar loops of polygonal shape with a diameter of $64.36 \pm 0.14 \mu \mathrm{m}$ and a muscular type of structure. From hypodermis to the dermis passed microvessels with a diameter of 46.08 $\pm 0.28 \mu \mathrm{m}$, which connecting together, formed a subdermal arteriolar network. At the edge of the papillary and reticular layers of the dermis, a network formed by arterioles with a diameter of $21.42 \pm 0.31 \mu \mathrm{m}$ was detected. Under the basement membrane, capillary loops with microvessels diameter $12.34 \pm 0.27 \mu \mathrm{m}$ were identified. Collecting venules formed the surface subpapillary plexus, diameter $61.5 \pm 0.35 \mu \mathrm{m}$. On the edge of papillary and mesenteric layers was a deep sub-papillary plexus, which consisted of venules with a diameter of $74.77 \pm 0.29 \mu \mathrm{m}$. Between the reticular layer and hypodermis a subdermal venular network was observed, formed by three-layer microvesells with a diameter of $107.38 \pm 0.55 \mu \mathrm{m}$. In the hypodermis, microvessels were identified with a diameter of $134.64 \pm 2.03 \mu \mathrm{m}$ that formed venous network. Pathological inclusions in the form of calcium salts, sediments of hemosiderin, amyloid, neutral and acidic glycosaminoglycans, as well as oxytalan and elaunin fibers were not detected.

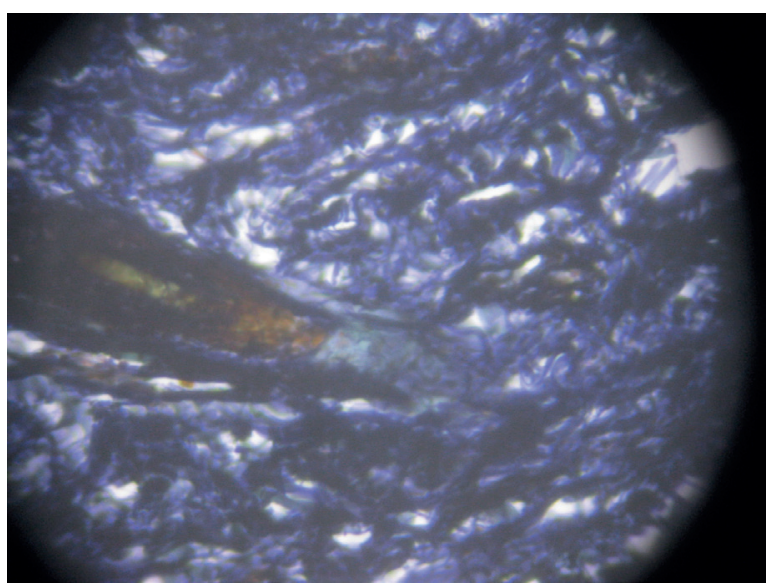

Fig. 2. Well-structured dense and fine-fibrous collagen fibers of the upper third of the dermis. The skin of the anterior abdominal wall of 5-months-old rat. Staining with picro-indigo carmin. $400 \times$ 
Collagen fibers were resistant to collagenase. The results were consistent with literature data on skin structure in healthy rats [13].

According to the results of light microscopy, 30 days after the start of the experiment in the basal layer of epidermis cells with signs of degenerative changes the following changes were observed: the cytoplasm contained vacuoles, inclusions, and the nuclei were swollen and displaced to the periphery. The basement membrane of the epidermis had small areas with thinning and thickening, which in both cases were accompanied by the formation of small and massive leukocyte infiltrates. Its edema was noted, which extended to the papillary and reticular layer of the dermis. Elastic fibers were unchanged. Only $50 \%$ of the microvessels looked intact, $20 \%$ of microvessels were narrowed, and $30 \%$ had signs of stagnant hyperemia due to dilatation. The reticular layer of the dermis was infiltrated by leukocytes, their loci were observed around the blood vessels. In the hypodermic arteriolar networks, the microvessels were unchanged $(65.43 \pm 2.28$ $\mu \mathrm{m}, \mathrm{P}>0.05)$ compared to the intact group. The nuclei of the endothelial cells were weakly contoured, translocated to the lumen of the microvessels. The inner elastic membrane was moderately gyrose, had small folds of various heights. Venules of the subdermal, hypodermic and deep subpapillary plexi were expanded (diameter $119.16 \pm 2.57 \mu \mathrm{m}, \mathrm{P}<0.05$ ), $151.2 \pm$ $1.4 \mu \mathrm{m}, \mathrm{P}<0.05,84.1 \pm 1.25 \mu \mathrm{m}, \mathrm{P}<0.05$, respectively), induration of their walls was observed. In the reticular layer of the dermis the average diameter of arterioles decreased $(30.4 \pm 1.88 \mu \mathrm{m}, \mathrm{P}<0.01)$, and collective venules of the surface subpapillary plexus, on the contrary, increased (70.2 $\pm 0.96 \mu \mathrm{m}$, $\mathrm{P}<0.05)$. The diameter of the arterioles at the edge of the papillary and mesenteric layers and the capillary loops under the basement membrane virtually decreased $(15.25 \pm 0.78 \mu \mathrm{m}$, $\mathrm{P}<0.01,7.44 \pm 0.51 \mu \mathrm{m}, \mathrm{P}<0.001$, respectively). Due to edema of the walls of endothelial cells in blood capillaries, there was a decrease of their lumen, which led to the formation of red blood cell aggregates. Diapedesis of red blood cells and sometimes microhemorrhages were observed. Grouping of a significant number of leukocytes, fibroblasts, macrophages were revealed around the capillaries of the papillary layer of the dermis. Fibroblasts were large, with marked cytoplasmic basophilia. The contours of the collagen fibers of the dermis were indistinct, the areas of their homogenization and fragmentation were noted (Fig. 3).

The study of tissue basophils revealed that their morphological and quantitative characteristics in the dermis and hypodermis were similar to intact. Only the level of their metachromasia varied: the number of dark cells moderately reduced, the number of light cells increased, the most significant changes were observed in the hypodermis. Degranulation processes were suppressed along with simultaneous reduction of the number of tissue basophils with average and weak granules saturation. It was established that in the papillary layer of the dermis, the number of degranulating cells decreased by 1.8 times, in reticular layer by 2.1 , respectively, in the hypoderm - by 2.8

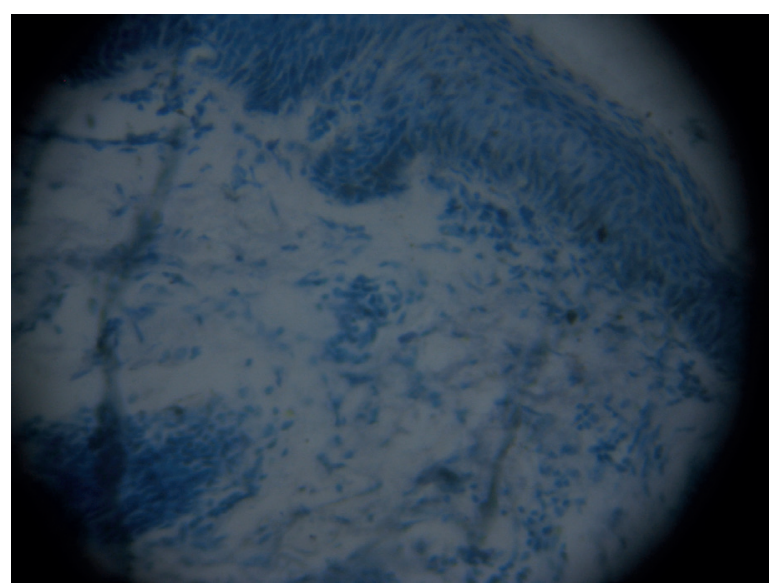

Fig. 3. Around the capillaries of the papillary layer of the dermis a significant number of grouped leukocytes, fibroblasts, macrophages is observed. The indistinct contours of the dermal collagen fibers are seen as well as the areas of their homogenization and fragmentation. The skin of the anterior abdominal wall of a 6-months-old rat after 30 days of the start of the experiment. Staining with toluidine blue 
times. The changes mentioned above led to the reduction of the saturation index and a decrease in the degranulation index.

Sixty days after the experiment began, the epidermis was thinned, in basal epidermis the loci of the cytoplasm vacuolization were found and perinuclear edema in the form of a ring-shaped rim was observed. In the basal layer of the epidermis the cells with picnotized and displaced to the periphery nucleus were detected, which acquired a flattened form due to the pronounced vacuolization of the cytoplasm. In the epidermis, the zones of hydropic dystrophy were revealed, what was accompanied by severe edema, ballooning degeneration, loss of intercellular bridges and spongiosis (Fig. 4).

The morphology of the connective tissue of the dermis remained unchanged. Only in zones of severe edema loci of homogenization and fragmentation of collagen fibers and induration of the elastic fibers were noted. In these areas the signs of congestive hyperemia, perivascular edema, diapedesis of blood cells into the extravascular space and macrophage

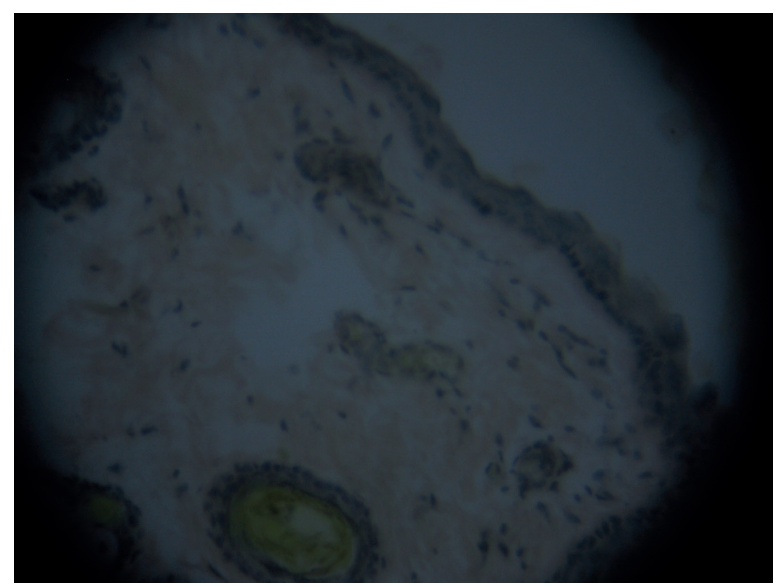

Fig. 4. The thinned epidermis, loci of vacuolization of the cytoplasm of basal epidermocytes and perinuclear edema. In the basal layer of epidermis the cells with picnotic and displaced to the periphery nucleus were detected, which acquired a flattened form due to the pronounced vacuolization of the cytoplasm. In the epidermis, the zones of hydropic dystrophy and significant edema are revealed. The skin of the anterior abdominal wall of the 7-month-old rat after 60 days from the beginning of the experiment. The staining with hematoxylin and eosin. $400 \times$ migration were seen. As a result of edema, the spaces between collagen fibers increased, and sometimes their homogenization was observed (Fig. 5). Skin appendages remained intact.

In the hypodermic arteriolar network, the microvessels were dilated $(74.18 \pm 0.92 \mu \mathrm{m}$, $\mathrm{P}<0.05)$ compared to intact control to the vessels after 30 days of the experiment. Venules of sub-, hypodermal and deep subpapillary plexuses were expanded (diameter 118.45 \pm 3.21 $\mu \mathrm{m}, \mathrm{P}<0.05,153.4 \pm 2.73 \mu \mathrm{m}, \mathrm{P}<0.05,80.43 \pm$ $2.51 \mu \mathrm{m}, \mathrm{P}<0.05$, respectively), the formation of perforations and the swelling of their walls was detected. In the reticular layer of the dermis, the mean diameter of the arterioles $(39.8 \pm 3.1$ $\mu \mathrm{m}, \mathrm{P}<0.05)$ decreased and the venules of the surface subpapillary plexus increased (74.6 \pm $2.25 \mu \mathrm{m}, \mathrm{P}<0.05)$.

The diameter of arterioles on the edge of papillary and reticular layers increased to the control level $(21.54 \pm 1.94 \mu \mathrm{m}, \mathrm{P}<0.05)$. The diameter of the capillary loops under the basement membrane didn't change in comparison with the vessels after 30 days of the experiment $(12.62 \pm 0.97 \mu \mathrm{m}, \mathrm{P}>0.05)$. In the reticular layer of the dermis, especially on

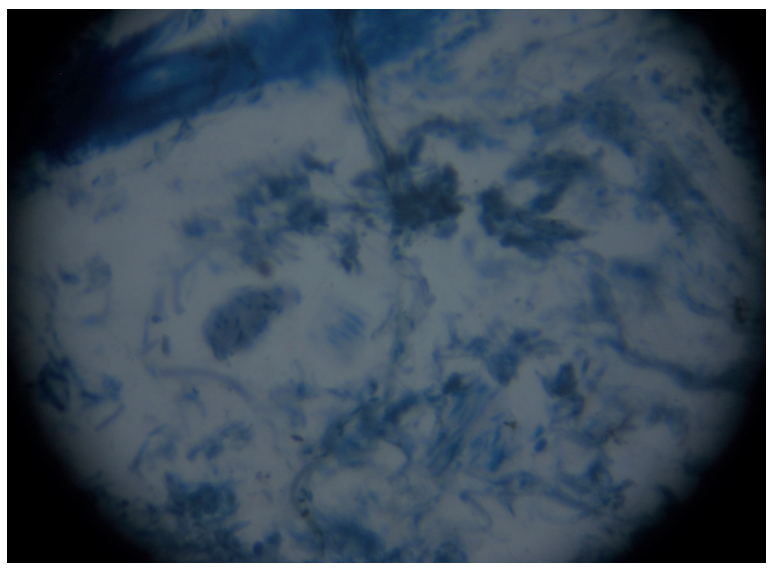

Fig. 5. Loci of homogenization and fragmentation of collagen fibers. The signs of congestive hyperemia, perivascular edema, diapedesis of blood cells into the extravascular space and macrophage migration. As a result of edema, the spaces between collagen fibers are increased, the homogenization is noted. The skin of the anterior abdominal wall of the 7-monthold rat after 60 days from the beginning of the experiment. The staining with toluidine blue. 
the border with subcutaneous tissue, marked dilatation of blood vessels was revealed, collaret infiltrates that consisted of plasma cells, histiocytes, lymphocytes and macrophages were revealed around them. Tissue basophils, according to their morphological characteristics and the number in dermis and hypodermis, increased compared to intact specimens, the level of their metachromasia changed: the number of very dark and dark cells moderately increased, the number of light cells decreased, the most significant changes were identified in the hypodermis. The processes of degranulation enhanced along with simultaneous increase of the number of tissue basophils with moderate granules saturation. It was established that in the papillary layer of the dermis, the number of degranulating cells increased by 2.5 times compared to the control group, in the reticular layer by 3.1 , respectively, in the hypoderm - by 3.8 times. Thus, the activity of tissue basophils was the highest in the hypodermis and the lowest in the papillary layer of the dermis.

90 days after the start of the experiment, the epidermis was represented by 3-6 layers of cells, its general refinement was observed due to the reduction of the thickness of the spinous and granular layers with simultaneous thickening of the horny layer. Globe-shaped bodies and homogeneous acidophilic formations with pyknotic nuclei were identified, that indicated the violation of keratinization processes. The enlarged epidermocytes of spherical shape with cytoplasm basophilia and expressed granulation were seen. The number of promelanosomes, melanosomes and melanin granules was reduced. In basal epidermis nuclei pyknosis and cytoplasm homogenization were revealed as well as perinuclear vacuolization of the cytoplasm, indicative of their dystrophic changes. Areas of necrosis of the epidermis with segmented leukocyte infiltration were identified. In inflammatory infiltrates histocytes and fibroblasts were beginning to dominate. On the areas of the pronounced acanthosis, epidermis was translocating into the thick underlying tissues. The basement membrane of the epidermis was found thickened, also were found areas of its refinement, which was accompanied by fibrosis of the layers below the dermis. The dermis was edematous, especially in the papillary layer, focal leukocyte infiltration with the inclusion of macrophages was detected, increased number of fibroblasts. The number of derma fibroblasts was increased, signs of fibrosis were noted. In the reticular layer of the dermis, collagen bundles were swollen and fragmented (Fig. 6).

Collagen fibers changed the perception of fuchsine and looked from pale pink to purple-red, were indurated, the loci of their homogenization and fragmentation were identified, deposits of calcium on the surface of the fibers were detected. Incubation of slices in collagenase solution showed the decrease of the resistance to this enzyme, which turned out to be loci of dissolved collagen fibers, formation of fragments of collagen fibrils and homogeneous masses, which were not found in identical native specimens (Fig. 7).

Mature collagen fibers were contiguous with reticulin fibers, indicating their degenerative changes (Fig. 8).

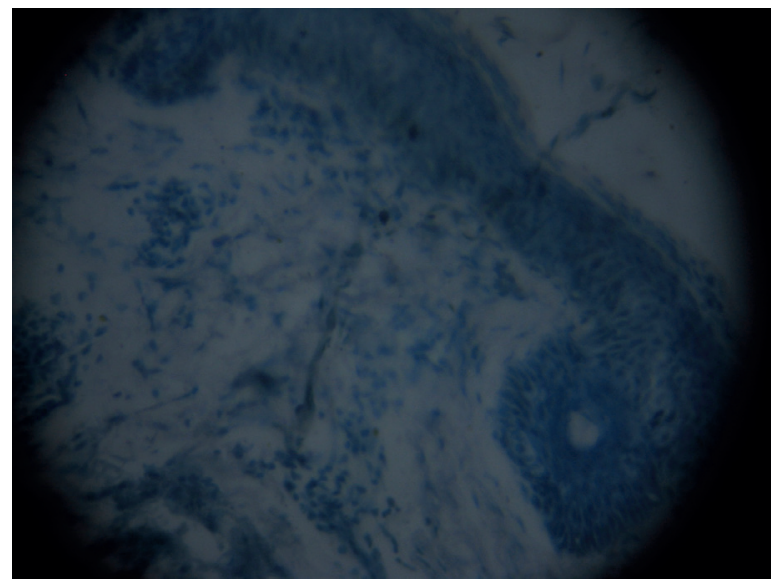

Fig. 6. The edema of dermis, focal leukocyte infiltration with macrophages involvement. The collagen fibers are fragmented, edematous, and indurated, loci of their homogenization are observed. The skin of the anterior abdominal wall of the 9-month-old rat after 90 days of the experiment beginning. Staining with toluidine blue. $400 \times$ 


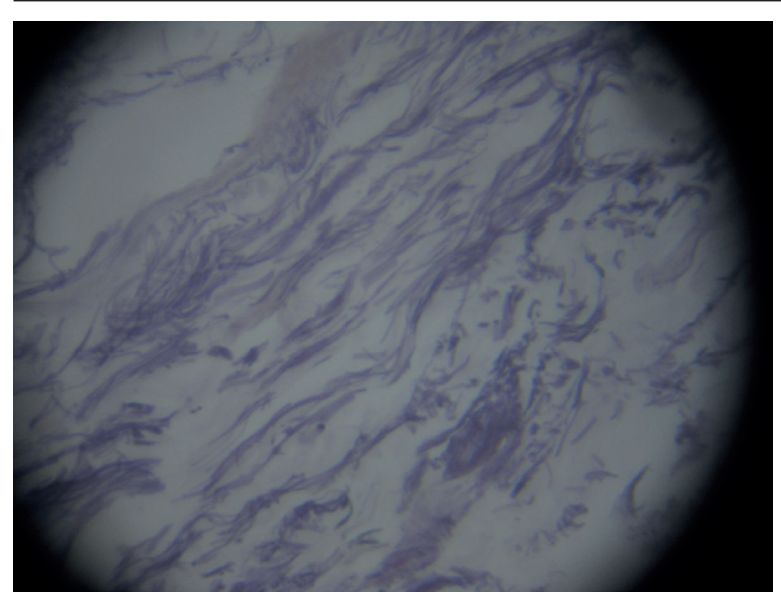

Fig. 7. Collagen fibers change the perception of fuchsine, are indurated, the loci of their homogenization and fragmentation can be identified. Incubation of slices in collagenase solution showed the decrease of the resistance to this enzyme, which turned out to be loci of dissolved collagen fibers, formation of fragments of collagen fibrils and homogeneous masses. The skin of the anterior abdominal wall of the 9-month-old rat after 90 days of the experiment beginning. Staining with resorcin-fuchsin according to Weigert. 400×

Elastic fibers were represented in large numbers, however, among them appeared partially fragmented, polymorphic and fragmented. Oxytalene and elaunin fibers, loci of hemosiderin deposition near microvessels were detected. Hair follicles were literally unchanged and densely located. The flattening of dermal papillae and degenerative changes in the sebaceous glands were noted. In the papillary layer of the dermis, the number of thin-walled blood vessels was increased. The average diameter of the arterioles of the hypodermis decreased gradually $(51.68 \pm 1.68 \mu \mathrm{m}, \mathrm{P}<0.05)$ compared to the values on the $1 \mathrm{st}, 30$ th and 60 th days. The diameter of the arterioles in the subdermal network increased and approached the values of intact animals $(42.42 \pm 1.1 \mu \mathrm{m}$, $\mathrm{P}>0.05)$. The mean diameter of the arterioles of the subdermal network on the border of the papillary and reticular layers $(12.22 \pm 0.81 \mu \mathrm{m}$, $\mathrm{P}<0.001)$ and capillary loops under the basal membrane $(6.84 \pm 0.51 \mu \mathrm{m}, \mathrm{P}<0.001)$ was reduced what can be a sign of sclerotic changes in the microvessels. The venules diameter

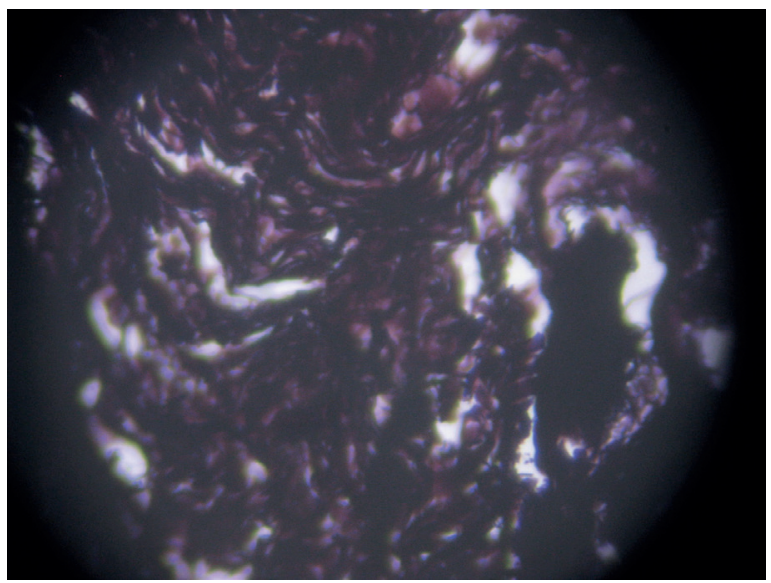

Fig. 8. Mature collagen fibers are contiguous with reticulin fibers, indicating their degenerative changes. The skin of the anterior abdominal wall of the 9-month-old rat after 90 days of the start of the experiment. Impregnation with silver according to Foot. $400 \times$

remained increased, making $94.15 \pm 1.44 \mu \mathrm{m}$ $(\mathrm{P}<0.01)$ in collecting venules of the surface subpapillary plexus, the diameter of collecting venules of deep subpapillary plexus made $133.6 \pm 3.03 \mu \mathrm{m}(\mathrm{P}<0.001)$, venules of the hypodermis plexus $-155.16 \pm 4.47 \mu \mathrm{m}(\mathrm{P}<0.05)$. But the diameter of subdermal plexus venules diminished to $96.32 \pm 4.34 \mu \mathrm{m}(\mathrm{P}<0.05)$. In arterioles and venules, stasis of the microvessels, edema of their walls, loss of contouring, microaneurysm and venous sacculation were detected. In the hemorrhages loci, clusters of young fibroblasts and isolated macrophages were detected. Changes in skin microvessels, which are marked in portal hypertension, we tend to regard as a result of the intensive violation of hemodynamics in the tissue, which is a complex chain of microcirculation restructuring toward the direct action of high pressure in the portal vein and is a secondary response to systemic vascular damage. In the walls of microvessels and collagen fibers accumulated PAS-positive material in the form of a moderate amount of neutral and acidic glycosaminoglycans (Fig. 9).

Morphofunctional features of tissue basophils of the dermis and hypodermis were similar to those in the previous period of studies. 


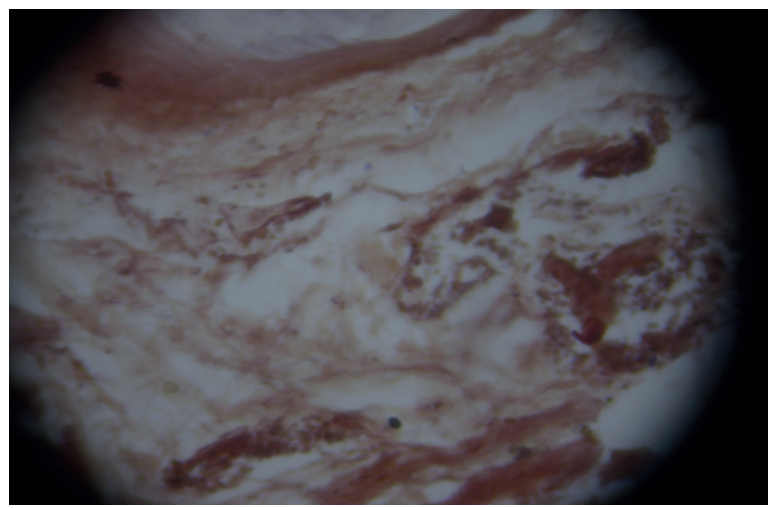

Fig. 9. PAS-positive material is accumulated in the walls of microvessels and collagen fibers in the form of a moderate amount of neutral and acidic glycosaminoglycans. The skin of the anterior abdominal wall of the 9-month-old rat after 90 days of the start of the experiment. Staining according to Schiff. $400 \times$

Skin changes that we observed in the period of 30-90 days after the start of the experiment (dystrophy, necrosis of the epidermis and surface layers of the dermis with pronounced vascular reaction), we tend to consider as a result of a profound violation of the skin microcirculation in response to its systemic damage. The growing inflammatory reaction in the skin is a secondary response to the violation of tissue trophic.

\section{CONCLUSION}

Light microscopy provides insufficient data to judge about the selective effect of high pressure in the microvessels on a certain anatomical structure of the skin (epidermis, connective tissue, blood vessels, etc.) that would help identify all the mechanisms of the development of skin lesions in portal hypertension. Perhaps, functional changes that occur first in the early stages of the pathological process development, lead to ultrastructural changes. These changes can be detected, in our opinion, with electron microscopy using the methods of electron histochemistry.

The authors of this study confirm that the research and publication of the results were not associated with any conflicts regarding commercial or financial relations, relations with organizations and/or individuals who may have been related to the study, and interrelations of co-authors of the article.

\section{Н.Р. Грицевич ${ }^{1}$, В.В. Верещака ${ }^{2}$ \\ ВПЛИВ ПОРТАЛЬНОЇ ГІПЕРТЕНЗІЇ НА СТАН ГЕМОМІКРОЦИРКУЛЯТОРНОГО РУСЛА ШКІРИ ЩУРІВ: МОРФОЛОГІЧНЕ ДОСЛІДЖЕННЯ}

\author{
${ }^{1}$ Вищчий навчальний комунальний заклад Львівської \\ обласної ради «Львівська медична академія ім. Андрія \\ Крупинського»; \\ ${ }^{2}$ Навчально-науковий центтр «Інститут біологї та \\ медииини» Київського національного університету імені \\ Tapaca Шевченка; е-mail:vvv090675@gmail.com
}

У роботі вивчали вплив портальної гіпертензії на стан гемомікроциркуляторного русла шкіри білих нелінійних щурів-самців. Гіпертензію моделювали накладанням лігатури на портальну вену за загальноприйнятою методикою. Через 30, 60 та 90 днів робили забір біоптатів шкіри з передньої черевної стінки для досліджень на світлооптичному рівні, які піддавали рутинній гістологічній обробці. У тварин контрольної групи, яким проводили удавану операцію, шкіра залишалася без змін. У щурів дослідної групи через 30 діб у базальному шарі епідермісу зустрічалися клітини з ознаками дегенеративних змін. Базальна мембрана епідермісу мала ділянки витончення і потовщення, що у обох випадках супроводжувалося утворенням лейкоцитарних інфільтратів. Відмічався ії набряк, який поширювався на сосочковий і сітчастий шар дерми. Спостерігалися зміни мікросудин: 20\% були звуженими, а 30\% мали ознаки застійного повнокрів'я внаслідок дилатації. Через 60 діб епідерміс витончувався, у базальному шарі виявлялися клітини із пікнотизованим та зміщеним до периферії ядром. У всіх досліджуваних шарах епідермісу, окрім сітчастого, спостерігалося розширення артеріол, венул і капілярних петель. Через 90 діб епідерміс був представлений 3-6 шарами клітин, спостерігалося загальне його витончення внаслідок зменшення товщини остистого та зернистого шарів при одночасному потовщенні рогового. У сосочковому шарі дерми число тонкостінних кровоносних судин було збільшеним. Середній діаметр артеріол гіподерми зменшувався відносно значень на 60-ту добу. Середній діаметр артеріол субдермальної сітки на межі сосочкового і сітчастого шарів і капілярних петель під базальною мембраною був зменшеним, що мало ознаки склеротичних змін мікросудин. Діаметр венулярної ланки залишався збільшеним. У артеріолах та венулах виявлялися стази мікросудин, набряк їх стінок, мікроаневризми та венозні сакуляції. Таким чином, зміни мікросудин шкіри, 
які відмічаються при портальній гіпертензії, ми вважаємо результатом порушення гемодінаміки у тканині, що $€$ складним ланцюгом перебудови гемомікроциркуляторного русла на пряму дію підвищеного тиску у портальній вені i $є$ вторинною відповіддю на системне судинне ураження. Ключові слова: портальна гіпертензія; морфологія; шкіра; мікроциркуляція.

\section{Н.Р. Грицевич,В.В. Верещака}

\section{ВЛИЯНИЕ ПОРТАЛЬНОЙ ГИПЕРТЕНЗИИ НА СОСТОЯНИЕ ГЕМОМИКРОЦИРКУЛЯ- ТОРНОГО РУСЛА КОЖИ КРЫС: МОРФОЛО- ГИЧЕСКОЕ ИССЛЕДОВАНИЕ}

В работе изучали влияние портальной гипертензии на состояние гемомикроциркуляторного русла кожи белых нелинейных крыс-самцов. Гипертензию моделировали наложением лигатуры на портальную вену по общепринятой методике. Через 30, 60 и 90 сут делали забор биоптатов кожи с передней брюшной стенки для исследований на светлооптическом уровне, которые подвергались рутинной гистологической обработке. У животных контрольной группы, у которых осуществляли мнимую операцию, кожа оставалась без изменений. У крыс опытной группы через 30 сут в базальном слое эпидермиса встречались клетки с признаками дегенеративных изменений. Базальная мембрана эпидермиса имела участки истончения и утолщения, что в обеих случаях сопровождалось образованием лейкоцитарных инфильтратов. Отмечался ее отек, который распространялся на сосочковый и сетчатый слой дермы. Наблюдались изменения микрососудов: $20 \%$ были сужены, а $30 \%$ имели признаки застойного полнокровия за счет дилатации. Через 60 сут эпидермис истончался, в базальном его слое были выявлены клетки с пикнотизованым и смещенным к периферии ядром. Во всех исследуемых слоях эпидермиса, кроме сетчатого, наблюдалось расширение артериол, венул и капиллярных петель. Через 90 сут эпидермис был представлен 3-6 слоями клеток, наблюдалось общее его истончение за счет уменьшения толщины остистого и зернистого слоев при одновременном утолщении рогового. В сосочковом слое дермы число тонкостенных кровеносных сосудов было увеличено. Средний диаметр артериол гиподермы уменьшался относительно значений на 60-е сутки. Средний диаметр артериол субдермальной сетки на границе сосочкового и сетчатого слоев и капиллярных петель под базальной мембраной уменьшался, что было признаком склеротических изменений в микрососудах. Диаметр венулярного звена оставался увеличенным. В артериолах и венулах наблюдались стазы микрососудов, отек их стенок, микроаневризмы и венозные сакуляции. Таким образом ,изменения микрососудов кожи, которые наблюдались при портальной гипертензии, мы считаем результатом нарушения гемодинамики в тканях. В свою очередь они являются сложной цепью перестройки гемомикроциркуля- торного русла на прямое действие повышенного давления в портальной вене и вторичным ответом на системное сосудистое поражение.

Ключевые слова: портальная гипертензия; морфология; кожа; микроциркуляция.

\section{REFERENCES}

1. Snegyrev FG. Progress and future of Ukrainian surgery. Ukr Med J. 2019;1(1)-I/II.

2. Syiromaha C. Cardiac surgery in Ukraine: problems and prospects of a progressive industry. 2015;amnu.gov.ua> Naukova diyalnyst [Research activities].

3. Vereshchaka VV. Pathophysiological mechanismes of the resistantionalreduce of skin capillary in case of patientes. Fiziol Zh. 2000;46(6):116-8. [Ukrainian].

4. Kalyuzhnaya LD, Vereshchaka VV. Functional state of the skin in its premature involution. Probl Aging Develop. 2002;6(2):193-8.

5. Cherkasov VG, Vereshchaka VV. Ultrastructural changes of facial skin in the process of aging of modern Caucasian type. Rep Morphol. 2005;(2):203-6. [Ukrainian].

6. Van der Graaff D, Kwanten WJ, Couturier FJ, Govaerts JS, Verlinden W, Brosius I, D’Hondt M, Driessen A, De Winter BY, De Man JG, Michielsen PP, Francque SM. Severe steatosis induces portal hypertension by systemic arterial hyporeactivity and hepatic vasoconstrictor hyperreactivity in rats. Lab Invest. 2018;98(10):1263-75.

7. Schwabl P, Brusilovskaya K, Supper P, Bauer D, Königshofer P, Riedl F, Hayden H, Fuchs CD, Stift J, Oberhuber G, Aschauer S, Bonderman D, Gnad T, Pfeifer A, Uschner FE, Trebicka J, Rohr-Udilova N, Podesser BK, Peck-Radosavljevic M, Trauner M, Reiberger T. The soluble guanylate cyclase stimulator riociguat reduces fibrogenesis and portal pressure in cirrhotic rats. Sci Rep. 2018 Jun 19;8(1):9372.

8. Königshofer P, Brusilovskaya K, Schwabl P, Reiberger T. Animal models of portal hypertension. Biochim Biophys Acta Mol Basis Dis. 2019 May1;1865(5):1019-30.

9. Sarkisov DS, Perov YuL, editors. Microscopic technique: Manual. Moscow: Medicine; 1996.

10. Tsvetkova GM, Mordovtsev VN. Pathomorphological Diagnostics of Skin Diseases: Manual. - Moscow: Medicine; 1986.

11. Avtandilov GG. Fundamentals of Quantitative Pathological Anatomy: Study Manual. Moscow: Medicine; 2002.

12. Filimonova NB, Fil IO, Mykhailova TS. Statistical analysis of data in accordance with the principles of science of sound medicine. Medicine of Ukrainian Transport. 2004;4:85-93.

13. Diskovskyi IS. Morphological peculiarities of the skin and reparation processes under the influence of opioid in experiment. Thesis for a Candidate Degree in Medicine: specialty 14.03.01 - normal anatomy. - Ivano-Frankivsk National Medical University, Ministry of Health of Ukraine, Ivano-Frankivsk, 2016.

Received 17.05.2021 